\title{
Harnessing Proficient Rhizobacteria to Minimize the Use of Agrochemicals
}

\author{
Ruchi Sharma*, Anupma Dahiya and Satyavir Singh Sindhu \\ Department of Microbiology, College of Basic Sciences and Humanities, CCS Haryana \\ Agricultural University, Hisar - 125 004, India \\ *Corresponding author
}

\begin{tabular}{|l|}
\hline \multicolumn{1}{|l}{} \\
\hline K e y w o r d s \\
Agrochemicals, \\
Environmental pollution, \\
Rhizosphere bacteria, \\
Biofertilizers, \\
Biopesticides, Sustainable \\
agriculture
\end{tabular}

A B S T R A C T

Humanity is facing a major challenge in producing enough food from the limited resources for an additional three billion people by 2050 . Moreover, the productivity of agricultural crops is adversely affected due to environmental abiotic and biotic stresses. To meet the global food demand, intensive agriculture has resulted in indiscriminate use of chemical fertilizers and pesticides. These agrochemicals and their metabolites have been found to cause pollution in soil, groundwater and atmosphere. To reduce the deleterious effects of these agrochemicals, certain potential microorganisms have been characterized from rhizosphere of different crop plants which can act as biofertilizers and biopesticides. These are considered to be safer alternatives and their application has increased significantly in recent times. Biofertilizers enhance plant growth by a wide variety of mechanisms including phosphate and potassium solubilization, siderophore production, biological nitrogen fixation, production of 1-aminocyclopropane-1-carboxylate (ACC) deaminase and phytohormone production. Biopesticides can control various plant diseases by production of antifungal compounds like antibiotics, siderophores, hydrolytic enzymes, $\mathrm{HCN}$, volatile organic compounds (VOCs) and by induction of systemic resistance. Further, understandings of the different rhizobacteria mediating plant growth promotion mechanisms could be exploited to enhance productivity of crops in sustainable agriculture.

\section{Introduction}

The ever-increasing population growth combined with the changing diets, would result in a unpredicted increase in food demand by 2050 (Bruinsma, 2009). On the other hand, agricultural sector is facing burden from many ways via lower soil nutrients, attack of pathogens, pests and weeds, and fluctuating climatic conditions. Severe global economic losses to agricultural crops are encountered annually due to plant diseases caused by pathogens leading to the loss of
$30 \%$ crop yield (Kumar, 2012). Fertilizers play an axial role in enhancing the food production especially after the introduction of high yielding crop varieties. Moreover, extensive use of agrochemicals in plant protection strategies in many agro-ecosystems to control pests, diseases and weeds resulted in health risks and caused other undesirable effects. The increasing public concerns and growing awareness about the potential adverse environmental effects as well as health hazards associated with the use of synthetic plant protection and other agrochemicals has 
prompted search for the sustainable technologies and products which are safer for the end users and the environment. An integrated crop management approach needs to be deployed to counteract degradation of the agro-ecosystem due to the on-going intensive agriculture. This includes the use of biofertilizers and biopesticides, integrated pest management, soil and water conservation practices along with biodiversity conservation.

The policies supporting sustainable agricultural production and extensive research has improved the effectiveness and consistency of microbial inoculants, which has resulted in the characterization of several strains for both biocontrol (Fravel, 2005; Sindhu et al., 2016) and biofertilization (Podile and Kishore, 2006), with mycorrhizal fungi and PGPR (plant growth promoting rhizobacteria) preparations. Natural pesticides are environment friendly and safer than classical chemical pesticides. The rhizosphere zone, supports large and active microbial population of rhizobacteria (root colonizing bacteria) that exert the beneficial effects on the growth of the host plant (Ahmad et al., 2008). Therefore, tremendous efforts are being made recently to develop such microbial inoculants which have beneficial plant growth properties leading to enhanced crop productivity in sustainable agriculture (Barriuso et al., 2008). Such beneficial properties of microbial inoculants could be manifested either by direct promotion of plant growth through increased nutrient availability or phytohormone production or by indirectly protecting plants from phytopathogens, or by fortifying certain abiotic stress tolerance in plants that grow in soils with extremes of high and low temperature, salinity, drought, acidity and presence of heavy metals (Kang et al., 2014; Chaudhary and Sindhu, 2015) (Fig. 1). Application of microbial inoculant approaches to these crops can contribute efficiently to solve or reduce the stress problems.
Successful application of rhizobacteria to crops facing biotic/abiotic constraints requires understanding of the target species and the mechanisms underlying resistance/ tolerance to these stresses (Goswami et al., 2016).

Understanding of the interactions between naturally-occurring PGPRs and with crop plants could foster the design of agro-systems with decreased fertilizer inputs and improved plant yields (Table 1). The most widely explored plant beneficial trait is the symbiotic biological nitrogen fixation by rhizobia (Udvardi and Poole, 2013; Sindhu et al., 2018), but numerous other nutrient acquisition machineries have been observed which facilitate plant access to macro- and micronutrients. Therefore, it is necessary to increase our understanding of the specific aspects of the defence/stress responses in agriculture in order to solve some of the major constraints facing these crops. The relevant advances in microbial inoculant approaches, applications and their functional analysis are discussed to overcome productivity losses and to minimize the environmental pollution.

\section{Biofertilizers: Mechanism of action}

Biofertilizers, colonize the rhizosphere or the interior of the plant and promote growth by increasing the supply or availability of nutrients to the host plant. The microorganisms commonly used as biofertilizers may be nitrogen-fixing soil bacteria (Rhizobium, Azotobacter) and cyanobacteria (Anabaena), phosphate solubilizing bacteria (Pseudomonas putida) and arbuscular mycorrhizal fungi. A number of rhizobacteria, which stimulated root and shoot growth of different plant species were found to contain the enzyme 1aminocyclopropane-1-carboxylate (ACC) deaminase that hydrolysed the ethylene precursor ACC to ammonia and $\alpha$ ketobutyrate, and as a result, decreased 
ethylene biosynthesis by plants (Belimov et al., 2001; Khandelwal and Sindhu, 2013). Another category of PGPM (plant growth promoting microorganisms) contains phytostimulators which are generally auxinproducing bacteria that induce root elongation (Lugtenberg et al., 2002). Mycorrhizal fungi were reported to promote plant growth through P uptake (Koide and Mosse, 2004). Similarly, phytohormone producing bacteria and cellulolytic microorganisms could also be part of biofertilizer formulation. When applied to the field, the beneficial activities such as nitrogen fixation, phosphate solubilization, production of phytohormones resulted in improved growth and productivity (Brar et al., 2012; Sangwan et al., 2012).

Nitrogen fixing biofertilizers fix atmospheric nitrogen into forms which are readily utilizable by plants. These include Rhizobium, Azotobacter and Azospirillum and blue green algae (BGA). While Rhizobium requires symbiotic association with the root nodules of legumes to fix nitrogen (Fig. 2), other microorganisms can fix nitrogen independently. Co-inoculation studies with rhizobia and PGPR are becoming a frequent practice in the development of sustainable agriculture (Table 2). PGPR tested as coinoculants with rhizobia include $B$. subtilis, Bacillus thuringiensis, Azospirillum brasiliense, Serratia proteomaculans, Serratia liquefaciens and Pseudomonas aureofaciens. Cassán et al., (2009) used A. brasilense, which produced IAA, GA3 and zeatin and it is a clear example of phytostimulation. Phosphate solubilizing microorganisms such as Bacillus, Pseudomonas, Aspergillus etc. secrete organic acids which enhance the uptake of phosphorus by plants by dissolving rock phosphate. Some other bioinoculants include potassium mobilizers and zinc solubilizers (Saravanan et al., 2004; Parmar and Sindhu, 2018; Sindhu et al., 2018). A considerable research has been done to establish the effectiveness of biofertilizers on various crops, in different agro-climatic regions. However, their effectiveness is found to vary greatly, depending largely on soil conditions, temperature and farming practices. However, biofertilizers are safe alternative to chemical fertilizers to minimize the ecological disturbance and they are cost effective and eco-friendly. They increase crop yield by $10-$ $40 \%$ and counteract the negative impact of chemical fertilizers.

\section{Biopesticides: Mechanism of action}

Pests are one of the major problems in crop protection and a major portion of expenditure on pesticides is for protecting the crop in the field. There has been an estimated 67,000 pest species that damage agricultural crops (Ross and Lembi, 1985) and pest management is one of the important activities required to maximise crop production. Plant protection not only requires purchase of chemicals but considerable input is needed on implements and labour required for their repeated applications on the standing crop. The current pest management strategies adopted for the intensive agriculture rely heavily on synthetic chemical pesticides which cause adverse/harmful effects on beneficial organisms and leave toxic residues in food and feed. Increasing demands for residue-free crop produce, growing organic food market and easier registration than chemical pesticides are some of the key drivers of the biopesticide market (Kumar, 2012; Sindhu et al., 2017a).

The available biopesticides may be divided into three major categories: microbial, biochemical (or botanical) and plantincorporated protectants. Microbial pesticides consist of microorganism (bacteria, fungi, viruses or protozoans) or their derivatives and they have been successfully being used in controlling insect pests. One of the most widely used microbial biopesticides is 
Bacillus thuringiensis, popularly known as Bt. The bacterium produces crystalline proteins and specifically kills one or a few related insect species. Success stories of biopesticide in India include control of diamondback moths by Bacillus thuringiensis, control of mango hoppers, mealy bugs and coffee pod borers by Beauveria, control of Helicoverpa on cotton, pigeon pea and tomato by Bacillus thuringiensis, control of white fly on cotton by neem products, control of sugarcane borers by Trichogramma, and control of rots and wilts in various crops by Trichoderma-based products. These biopesticides do not have residue problem which is a matter of significant concern for consumers, particularly for fruits and vegetables. When used as a component of IPM, efficacy of biopesticides can be equal to the conventional pesticides, especially for crops like fruits, vegetables, nuts and flowers. By combining performance and environmental safety, biopesticides perform efficaciously with the flexibility of minimum application restrictions and superior resistance management potential.

The suppression of growth of soil-borne plant pathogens by the use of microorganisms, to reduce the effects of harmful organisms (pests) is referred to as biocontrol. Rhizobacteria inhibit the growth of various pathogenic bacteria and fungi resulting in suppression of the diseases caused by such pathogens (Thomashow and Weller, 1996; Sindhu et al., 2002; Sharma et al., 2018).

Disease suppression by biocontrol agents involves a sustained manifestation of interactions among the plant, the pathogen, the biocontrol agent, the microbial community on and around the plant and the physical environment (Pierson and Weller, 1994). Strains of Pseudomonas fluorescens, $P$. putida, $P$. aureofaciens, $P$. cepacia and $P$. aeruginosa have been found to antagonize the growth of pathogens leading to substantial disease control (Weller, 2007). Jamali et al., (2003) studied effect of antagonistic B. subtilis strain Pf-100 on control of Fusarium wilt under greenhouse conditions. Usually general relationship was not observed between the ability of a bacterium to inhibit a pathogen under in vitro and in situ disease suppression (Schroth and Hancock, 1982; Wong and Baker, 1984). Bacterial strains producing the largest zones of fungal growth inhibition on agar media, do not always make the best biocontrol agents. Therefore, some in vitro conditions have been modified to more closely simulate natural conditions (Randhawa and Schaad, 1985). Souagui et al., (2015) isolated actinobacteria (Streptomyces) from rhizosphere of Ononis angustissima Lam. growing in extreme environment in southern of Algeria (Biskra, Sahara of Algeria). Four isolates i.e., 21, 2A26, 1B10 and 2C34 showed potent antagonism against both pathogenic bacteria and fungi.

Four Streptomyces sp. produced extracellular fungal cell-wall degrading enzymes (chitinase and protease), solubilized phosphate and also produced relatively high levels of IAA. In vivo biocontrol assays revealed that the Streptomyces strains significantly promoted the growth of the chickpea plants and showed greater suppression of chickpea wilt disease caused by Fusarium oxysporum. Among the numerous examples of biocontrol agents reported for disease control of soil-borne pathogens, only few studies provide mechanistic information for the activities of these biocontrol agents.

Weeds are another category of agricultural pests, causing great yield loss and labor expense (Schonbeck, 2011). Agricultural weeds can emerge rapidly, resulting in reduction of crop plant growth and quality by competing for nutrients and water provided to crops. 
Table.1 Categories of beneficial rhizobacteria and their mechanism of action involved in stimulation of plant growth

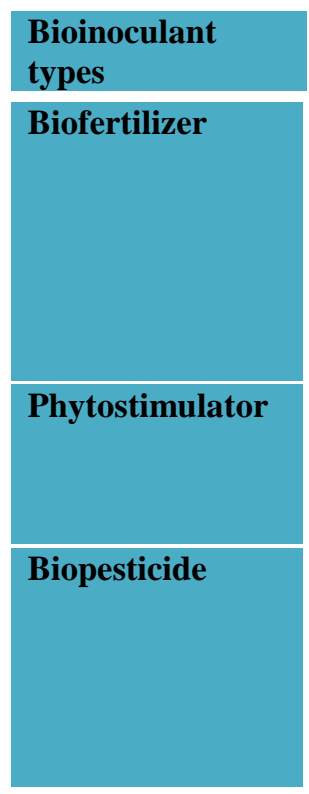

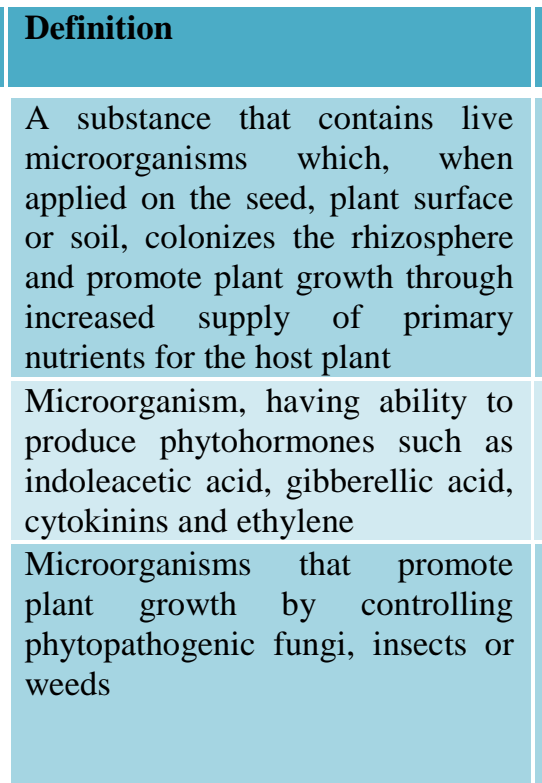

\begin{tabular}{|c|c|}
\hline Mechanism of action & References \\
\hline $\begin{array}{l}\text { Biological nitrogen } \\
\text { fixation } \\
\text { Utilization of insoluble } \\
\text { phosphorus } \\
\begin{array}{l}\text { Solubilization of bound } \\
\text { potassium and zinc }\end{array}\end{array}$ & $\begin{array}{l}\text { Vessey } \\
\text { Chaudhary and Sindhu } \\
(2016) \text {, Somers et al., } \\
(2004), \\
\text { Sravanan et al., (2004), } \\
\text { Sindhu et al., (2016) }\end{array}$ \\
\hline $\begin{array}{l}\text { Production } \\
\text { phytohormones }\end{array}$ & $\begin{array}{l}\text { Lugtenberg et al., (2002), } \\
\text { Somers } \text { et al., (2004) } \\
\text { Malik and Sindhu (2011) }\end{array}$ \\
\hline $\begin{array}{l}\text { Production of antibiotics, } \\
\text { HCN, siderophores, } \\
\text { hydrolytic enzymes, and } \\
\text { induced r systemic } \\
\text { resistance, } \\
\text { Phytotoxins and IAA }\end{array}$ & $\begin{array}{l}\text { Sindhu et al., (2016) } \\
\text { Somers } \text { et al., (2004) } \\
\text { Yasuda et al., (2008) } \\
\text { Sindhu and Sehrawat } \\
(2017)\end{array}$ \\
\hline
\end{tabular}

Table.2 Different rhizobacteria used as bioinoculant for various crop types

\begin{tabular}{|c|c|c|c|c|}
\hline PGPR & Crop & $\begin{array}{l}\text { Conditions } \\
\text { tested }\end{array}$ & Observed effects & Reference \\
\hline $\begin{array}{l}\text { Pseudomonas sp. } \\
\text { PS1 }\end{array}$ & $\begin{array}{l}\text { Green gram (Vigna } \\
\text { radiata } \\
\text { wilczek) }\end{array}$ & Pots & $\begin{array}{l}\text { Significantly increased plant dry } \\
\text { weight, nodule numbers, total } \\
\text { chlorophyll content, } \\
\text { leghaemoglobin, root } \mathrm{N} \text {, shoot } \mathrm{N} \text {, } \\
\text { root } \mathrm{P} \text {, shoot } \mathrm{P} \text {, seed yield and seed } \\
\text { protein }\end{array}$ & $\begin{array}{l}\text { Ahemad and } \\
\text { Khan (2012) }\end{array}$ \\
\hline $\begin{array}{l}\text { Rhizobium strain } \\
\text { MRP1 }\end{array}$ & $\begin{array}{l}\text { Pea } \\
\text { sativum })\end{array}$ & Pots & $\begin{array}{l}\text { Significantly increased the growth, } \\
\text { symbiotic properties (nodulation } \\
\text { and leghaemoglobin content), } \\
\text { amount of } \mathrm{N} \text { and } \mathrm{P} \text { nutrients in } \\
\text { plant organs, seed yield and seed } \\
\text { protein of pea plants }\end{array}$ & $\begin{array}{l}\text { Ahemad and } \\
\text { Khan (2011) }\end{array}$ \\
\hline $\begin{array}{l}\text { Rhizobium strain } \\
\text { GSA6, GSA11 } \\
\text { orGSA110 }\end{array}$ & $\begin{array}{l}\text { Clusterbean } \\
\text { (Cyamopsis } \\
\text { tetragonoloba L.) }\end{array}$ & Chillum jar & $\begin{array}{l}\text { Increased nodulation efficiency, } \\
\text { plant biomass }\end{array}$ & $\begin{array}{l}\text { Khandelwal and } \\
\text { Sindhu (2012) }\end{array}$ \\
\hline $\begin{array}{l}\text { Azorhizobium } \\
\text { caulinodans } \\
\text { strains Sb3, S78 }\end{array}$ & Sesbania bispinosa & Pots & $\begin{array}{l}\text { Enhanced nodule mass, nitrogenase } \\
\text { activity and plant dry weight }\end{array}$ & $\begin{array}{l}\text { Saini et al., } \\
(2003)\end{array}$ \\
\hline Pseudomonas sp. & $\begin{array}{l}\text { Soybean, } \\
\text { mungbean, wheat }\end{array}$ & Pots & Promoted growth of plants & $\begin{array}{l}\text { Gupta et al., } \\
\text { (2002); Sindhu } \\
\text { et al., (1999) }\end{array}$ \\
\hline $\begin{array}{l}\text { Mezorhizobium } \\
\text { strain MBD26 }\end{array}$ & Chickpea & Chillum jar & $\begin{array}{l}\text { Salinity tolerance and improved } \\
\text { plant growth }\end{array}$ & $\begin{array}{l}\text { Chaudhary and } \\
\text { Sindhu (2015) }\end{array}$ \\
\hline $\begin{array}{l}\text { Pseudomonas } \\
\text { isolate HCS36 }\end{array}$ & $\begin{array}{l}\text { Clusterbean } \\
\text { (Cyamopsis } \\
\text { tetragonoloba L.) }\end{array}$ & Pots & $\begin{array}{l}\text { Control of root rot disease, } \\
\text { increased nodulation, plant biomass }\end{array}$ & $\begin{array}{l}\text { Chaudhary and } \\
\text { Sindhu (2015) }\end{array}$ \\
\hline
\end{tabular}


Table.3 List of some commercially available bioinoculants

\begin{tabular}{|c|c|c|}
\hline Trade name & Rhizobacteria & Crops tested \\
\hline Galtrol, Diegal, No gall & $\begin{array}{l}\text { Agrobacterium } \\
\text { radiobacter }\end{array}$ & Several crops \\
\hline $\begin{array}{l}\text { Epic, HiStick N/T, Kodiak, } \\
\text { Rhizo-Plus, } \quad \text { Serenade, } \\
\text { Subtilex }\end{array}$ & Bacillus subtilis & $\begin{array}{l}\text { Barley, beans, cotton, peanut, pea, rice and } \\
\text { soybean }\end{array}$ \\
\hline System & Bacillus subtilis & Bean, barley, cotton and peanut \\
\hline Blue Circle, Deny, Intercept & Burkholderia cepacia & $\begin{array}{l}\text { Alfalfa, barley, beans, clover, cotton, } \\
\text { maize, peas, sorghum, vegetables and } \\
\text { wheat }\end{array}$ \\
\hline
\end{tabular}

Fig.1 Schematic illustration of important mechanisms for plant growth promotion by PGPR

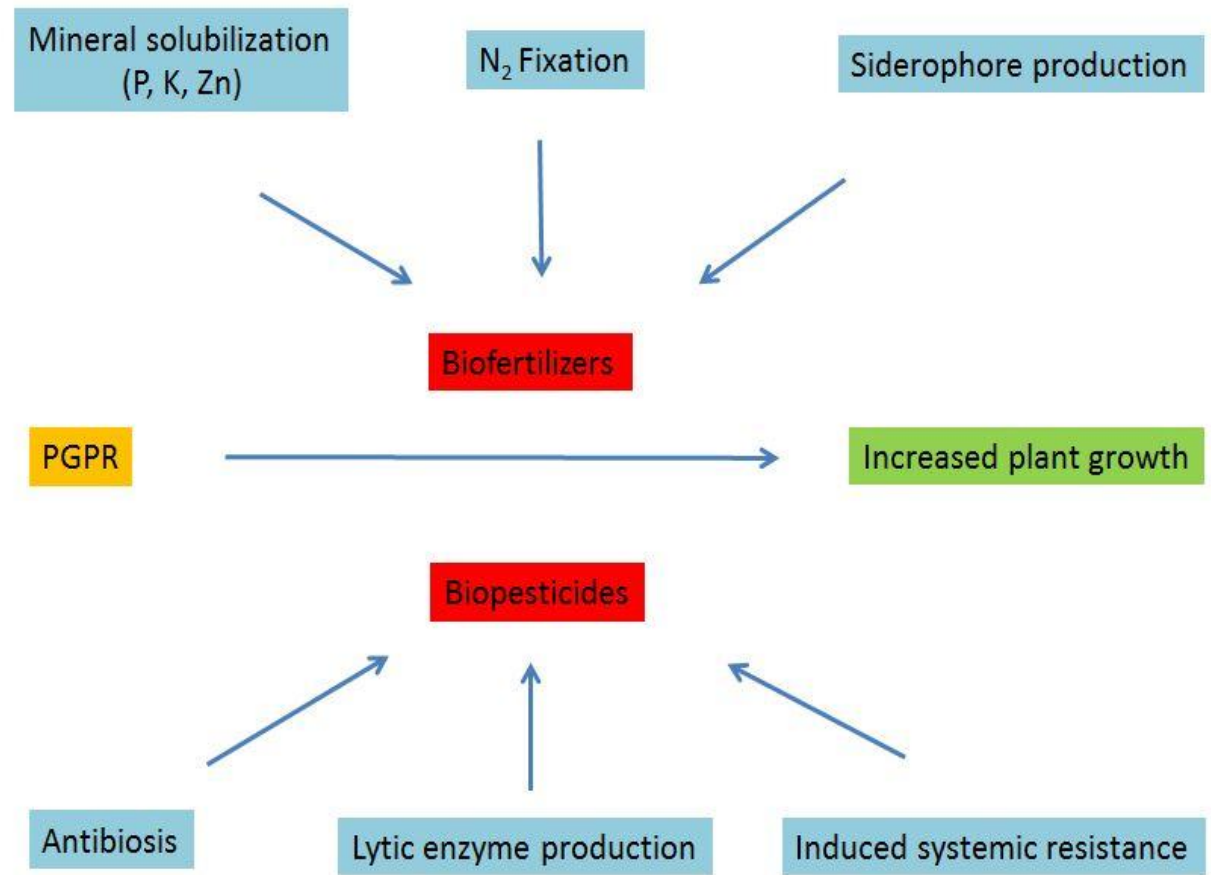

Fig.2 Increase in nodulation efficiency in chickpea (b) inoculated by rhizobacteria as compared to (a) uninoculated control

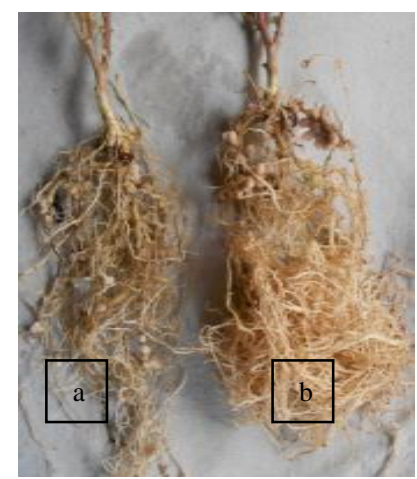


Annual weeds reproduce through prolific seed production and they germinate in response to light, increased fluctuations in soil temperature and moisture, improved aeration and accelerated nutrient release, while perennial weeds regenerate new plants from small fragments of roots, rhizomes, stolons and other underground structures. Severe weed problems present a serious threat to horticultural crop production with favorable environmental conditions in the soil. There have been many microbial agents under evaluation for their potential as bioherbicides with horticultural crops, turf and forest trees, including obligate fungal parasites, soil-borne fungal pathogens, non-phytopathogenic fungi, bacteria and nematodes (Sindhu et al., 2017b).

One of the first bioherbicides registered was DeVine (Encore Technologies, Plymouth, $\mathrm{MN}$, USA) with the active ingredient Phytophthora palmivora, which was developed to control strangler vine (Morrenia odorata) on citrus in Florida (Charudattan, 2005). The integration of biological control into current pest management systems may be an effective alternative for organic agricultural production. Biopesticide technology could be used as a component in integrated pest management strategies to help avoid pest resistance, reduce production costs and increased crop yield in organic farming. While there have been significant efforts to develop biopesticides, few have been registered for use. Future research should focus on the development of more costeffective and efficient biopesticides as well as the optimization of their use in agriproduction systems.

\section{Diverse PGPR molecules that elicit plant defense}

Various proteins and small molecules from PGPRs have been characterized that act by promoting plant defense pathways. Several uncharacterized proteins such as from Bacillus amyloliquefaciens NC6 (protein 'PeBA1') and the other from Brevibacillus laterosporus strain A60 (protein 'PeBL1') activate ISR responses in tobacco against tobacco mosaic virus (TMV) and $P$. syringae pv. tabaci and B. cinerea (Wang et al., 2015; 2016). The small molecule phenylacetic acid (PAA) is classified as an antimicrobial, but PAA isolated from Azospirillum brasilense was found to be similar to auxin (Somers et al., 2004). More recently, PAA from Bacillus fortisstrain IAGS162 was shown to be the elicitor of ISR in tomato against $F$. oxysporum f.sp. lycopersici (Akram et al., 2016). Through metabolomics techniques, Pseudomonas aeruginosa strain PM12 was found to promote ISR in tomato challenged with $F$. oxysporum via 3-hydroxy-5-methoxy benzene methanol (HMB). A soil drench of $1.0 \mathrm{mM}$ and $10.0 \mathrm{mM}$ HMB significantly reduced the disease index (Fatima and Anjum, 2017). The bacteriocin peptide Thuricin 17 (Th17) from the PGPR Bacillus thuringiensis strain NEB17, has long been known to have antimicrobial activities (Gray et al., 2006), but recent proteomic analysis of salt-stress Arabidopsis suggested that it may alleviate the deleterious effect of the abiotic stress on photosystems I and II through upregulation of chloroplast proteins (Subramanian et al., 2016).

\section{Commercialization of biofertilizers and biopesticides}

Several bacterial strains are commercially available in the form of formulated products which are used as biofertilizers and biocontrol agents (Sethi et al., 2014; Jha and Saraf, 2015) (Table 3). Since PGPRs have its own potentiality in controlling plant diseases and pest management, these commercial products such as Diegall, Galltrol-A, Zea-Nit, Epic, Quantum 4000, Victus, Mycostop etc. have 
therefore, been registered for the practical use of farming community. Besides, the potentiality of PGPR inoculants in improvement of agricultural plants in developing countries can never be ignored. In India, more than 40 stakeholders from different provinces have registered themselves for the mass production of PGPRs with Central Insecticide Board, Faridabad, Haryana through collaboration with Tamil Nadu Agricultural University, Coimbatore, India.

\section{Conclusion and future prospects}

Indian agriculture has undergone dynamic change since the "Green Revolution," which provided self-sufficiency and ushered in an era of rural prosperity. While the production of food grains increased fourfold, soil and environment health have been affected adversely by the application of 250 times more chemical fertilizers and 400 times higher applications of pesticides than needed (Teng, 2007). Biopesticides and biofertilizers have been reported to enhance the crop productivity by control of pests and providing nutrients in ecofriendly manner. They have been used in various forms and there is a large market potential for biofertilizer and biopesticide products that can only be tapped through a better understanding of rural markets and product/marketing constraints. To achieve these objectives, an extensive research and development efforts are needed in areas pertaining to production, quality assurance, field application and knowledge transmission of biocontrol and biofertilizer products.

In addition to the continuous search for new biomolecules and improving efficiency of the known biopesticides, recombinant DNA technology is being used for enhancing efficacy of biopesticides. Fusion proteins are being designed to develop next-generation biopesticides. The technology allows selected toxins to be combined with a carrier protein which makes them toxic to insect pests when consumed orally, while they were effective only when injected into a prey organism by a predator (Kumar, 2013). The fusion protein may be produced as a recombinant protein in microbial system, which can be scaled up for industrial production and commercial formulations. Several other innovative approaches are being applied to develop biopesticides as effective, efficient and acceptable pest control measure among the farmers. Deployed appropriately, biofertilizers and biopesticides have the potential to bring sustainability to global agriculture for food security.

Recently, the ability to 'engineer' the rhizosphere (Dessaux et al., 2016) may prove more effective as we move away from the current paradigm of species-based consortia and microbiome cataloguing (Maymon et al., 2015; Schlaeppi and Bulgarelli, 2015). The functions conferred by the changes in plant expression induced by the microbiome as a whole may prove to be more relevant than the specific microbe species enacting those changes, and the mechanisms by which the microbes act (Sindhu et al., 2017b). Thus, concomitant explorations of microbial genetic manipulation of the plant and chemical genomics approaches (Stokes and McCourt, 2014) to evaluate key microbial molecular components inducing plant beneficial responses could allow the understanding of PGPR action in the field. Sustainable PGPR applications may be developed for agricultural and horticultural management practices by identifying and elucidating the specific mechanisms of microbial-plant beneficial activity. Because crops are grown under a multiplicity of climatic and environmental conditions which change from farm to farm or even within one field, and such variations causes disparity in the 
potentiality of microbial inoculants based biofertilizers and biopesticides.

\section{References}

Ahemad, M., and Khan, M.S. 2011. Effect of pesticides on plant growth promoting traits of green gram-symbiont, Bradyrhizobium sp. strain MRM6. Bull. Environ. Contam. Toxicol, 86(4): 384388.

Ahemad, M., and Khan, M.S. 2012. Alleviation of fungicide-induced phytotoxicity in green gram [Vigna radiata (L.) Wilczek] using fungicide-tolerant and plant growth promoting Pseudomonas strain. Saudi J. Biol. Sci. 19(4): 451-459.

Ahmad, F., Ahmad, I., and Khan, M. S. 2008. Screening of free-living rhizospheric bacteria for their multiple plant growth promoting activities. Microbiol. Res. 163(2): 173-181.

Akram, W., Anjum, T. and Ali, B. 2016. Phenylacetic acid is ISR determinant produced by Bacillus fortis IAGS162, which involves extensive re-modulation in metabolomics of tomato to protect against Fusarium wilt. Front. Plant Sci., 7: 498 .

Barriuso, J., Solano, B.R., and Gutierrez Manero, F.J. 2008. Protection against pathogen and salt stress by four plant growth-promoting rhizobacteria isolated from Pinus sp. on Arabidopsis thaliana. Phytopathology 98(6): 666-672.

Belimov, A.A., Safronova, V.I., Sergeyeva, T.A., Egorova, T.N., Matveyeva, V.A., Tsyganov, V.E., and Dietz, K.J. 2001. Characterization of plant growth promoting rhizobacteria isolated from polluted soils and containing 1aminocyclopropane-1-carboxylate deaminase. Canadian J. Microbiol. 47(7): 642-652.

Brar, S.K., Sarma, S.J., and Chaabouni, E. 2012. Shelf-life of biofertilizers: An accord between formulations and genetics. J. Biofertil. Biopestici. 3:e109. doi:10.4172/2155-6202.1000e109.

Bruinsma, J. 2009. The resource outlook to 2050: By how much do land, water and crop yields need to increase by 2050 ? FAO Expert Meeting on 'How to Feed the World in 2050', Rome.

Cassan, F., Perrig, D., Sgroy, V., Masciarelli, O., Penna, C., and Luna, V. 2009. Azospirillum brasilense Az39 and Bradyrhizobium japonicum E109, inoculated singly or in combination, promote seed germination and early seedling growth in corn (Zea mays L.) and soybean (Glycine max L.). European J. of Soil Biol. 45(1): 28-35.

Charudattan, R. 2005. Ecological, practical, and political inputs into selection of weed targets: what makes a good biological control target? Biol. Contr. 35(3): 183196.

Chaudhary, D., and Sindhu, S.S. 2015. Inducing salinity tolerance in chickpea (Cicer arietinum L.) by inoculation of 1aminocyclopropane-1-carboxylic acid deaminase-containing Mesorhizobium strains. African J. Microbiol. Res. 9(2): 117-124.

Chaudhary, S.R. and Sindhu, S.S. 2016. Growth stimulation of clusterbean (Cyamopsis tetragonoloba) by coinoculation with rhizosphere bacteria and Rhizobium. Leg. Res.: An Internl J. 39(6): 1003-1012.

Choudhary, S.R., and Sindhu, S.S. 2015. Suppression of Rhizoctonia solani root rot disease of clusterbean (Cyamopsis tetragonoloba) and plant growth promotion by rhizosphere bacteria. Plant Pathol. J. 14: 48-57.

Dessaux, Y., Grandclément, C. and Faure, D. 2016. Engineering the rhizosphere. Trends in Plant Sci. 21(3): 266-278.

Fatima, S. and Anjum, T. 2017. Identification of a potential ISR determinant from Pseudomonas aeruginosa PM12 against Fusarium wilt in tomato. Front. Plant Sci. 8: 848-862. 
Fravel, D.R. 2005. Commercialization and implementation of biocontrol. Annual Rev. Phytopathol. 43:337-359.

Goswami, D., Thakker, J.N., and Dhandhukia, P.C. 2016. Portraying mechanics of plant growth promoting rhizobacteria (PGPR): A review. Cogent Food Agric. 2(1): 1127500.

Gray, K.J., Wilson, L.K., Phiri, A., Corkill, J.E., French, N. and Hart, C.A., 2006. Identification and characterization of ceftriaxone resistance and extendedspectrum $\beta$-lactamases in Malawian bacteraemic Enterobacteriaceae. J. Antimicrobial Chemother., 57(4): 661665.

Gupta, A., Meyer, J. M., and Goel, R. 2002. Development of heavy metal-resistant mutants of phosphate solubilizing Pseudomonas sp. NBRI 4014 and their characterization. Curr. Microbiol. 45(5): 323-327.

Jamali, F., Sharifi-Tehrani, A., Okhovvat, M., Zakeri, Z., and Saberi-Riseh, R. 2003. Biological control of chickpea Fusarium wilt by antagonistic bacteria under greenhouse condition. Commun. Agric. Appl. Biol. Sci. 69(4): 649-651.

Jha, C. K., and Saraf, M. 2015. Plant growth promoting rhizobacteria (PGPR): A review. E3 J. Agric. Res. Developm. 5: 108-119.

Kang, S.M., Khan, A.L., Waqas, M., You, Y.H., Kim, J.H., Kim, J.G. and Lee, I.J. 2014. Plant growth-promoting rhizobacteria reduce adverse effects of salinity and osmotic stress by regulating phytohormones and antioxidants in Cucumis sativus. J. Plant Interact. 9(1): 673-682.

Khandelwal, A. and Sindhu, S.S., 2013. ACC deaminase containing rhizobacteria enhance nodulation and plant growth in clusterbean (Cyamopsis tetragonoloba L.). J. Microbiol. Res., 3(3): 117-123.

Khandelwal, A., and Sindhu, S.S. 2012. Expression of 1-aminocyclopropane-1carboxylate deaminase in rhizobia promotes nodulation and plant growth of clusterbean (Cyamopsis tetragonoloba L.). Res. J. Microbiol. 7(3):158-170.

Koide, R.T., and Mosse, B. 2004. A history of research on arbuscular mycorrhiza. Mycorrhiza 14(3): 145-163.

Kumar S. 2013. The role of biopesticides in sustainably feeding the nine billion global populations. J. Biofertil. Biopestici. 4(2): $1-3$.

Kumar, S. 2012. Biopesticides: A need for food and environmental safety. J. Biofertil. Biopestici. 3:e107.

Lugtenberg, B.J., Chin-A-Woeng, T.F., and Bloemberg, G.V. 2002. Microbe-plant interactions: principles and mechanisms. Antonie Van Leeuwenhoek 81(1-4): 373383.

Malik, D.K. and Sindhu, S.S. 2011. Production of indole acetic acid by Pseudomonas sp.: effect of coinoculation with Mesorhizobium sp. Cicer on nodulation and plant growth of chickpea (Cicer arietinum). Physiol. Mol. Biol. Plants 17(1): 25-32.

Maymon, M., Martínez-Hidalgo, P., Tran, S.S., Ice, T., Craemer, K., Anbarchian, T., Sung, T., Hwang, L.H., Chou, M., Fujishige, N.A. and Villella, W. 2015. Mining the phytomicrobiome to understand how bacterial coinoculations enhance plant growth. Front. Plant Sci., 6: 784-798.

Parmar, P., and Sindhu, S.S. 2018. The novel and efficient method for isolating potassium solubilizing bacteria from rhizosphere soil. Geomicrobiol. J. 35(10): (In press).

Pierson, E.A., and Weller, D.M. 1994. To suppress take-all and improve the growth of wheat. Phytopathology 84: 940-947.

Podile, A.R., and Kishore, G.K. 2006. Plant growth-promoting rhizobacteria in PlantAssociated Bacteria, S. S. Gnanamanickam, Ed., pp. 195-230, Springer, Amsterdam, The Netherlands.

Randhawa, P.S., and Schaad, N.W. 1985. A seedling bioassay chamber for determining bacterial colonization and 
antagonism on plant roots. Phytopathology 75(3): 254-259.

Ross, M.A. and Lembi, C.A. 1985. Applied weed science. Burgess Publishing Co, Minneapolis.

Sangwan, V.P., Sindhu, S.S., Dahiya, O.S., and Kharb, R.P.S. 2012. Improvement of wheat (Triticum aestivum L.) yield under field conditions by inoculation of microbial strains. Microbiol. J. 2(3): 8695.

Saini, I., Sindhu, S.S., and Dadarwal, K.R. 2003. Symbiotic characterization of nitrate reductase deficient mutants of Azorhizobium caulinodans on Sesbania. Indian J. Microbiol. 43(4):227-231.

Saravanan, V.S., Subramoniam, S.R., and Raj, S.A., 2004. Assessing in vitro solubilization potential of different zinc solubilizing bacterial (ZSB) isolates. Brazilian J. Microbiol. 35(1-2): 121-125.

Schlaeppi, K. and Bulgarelli, D., 2015. The plant microbiome at work. Mol. PlantMicrobe Interact. 28(3): 212-217.

Schonbeck, M. 2011. Principles of sustainable weed management in organic cropping systems. In: Workshop for Farmers and Agricultural Professionals on Sustainable Weed Management, 3rd ed.; Clemson University: Clemson, SC, USA.

Schroth, M.N., and Hancock, J.G. 1982. Disease suppressive soil and root colonizing bacteria. Science 216(4553): 1376-1381.

Sethi, S.K., Sahu, J.K., and Adhikary, S.P. 2014. Microbial biofertilizers and their pilot-scale production. Microbial Biotechnol. : Progress and Trends 297.

Sharma, R., Sindhu, S. and Sindhu, S.S., 2018. Suppression of Alternaria blight disease and plant growth promotion of mustard (Brassica juncea L.) by antagonistic rhizosphere bacteria. Appl. Soil Ecol. 129: $145-150$.

Sindhu, S., Sharma, R., Masih, J.C., and Suneja, S. 2018. Prospects of zinc solubilizing bacteria as biofertilizer to promote growth of field crops. Annals Biol. 34(1): 16-23.
Sindhu, S.S. and Sehrawat, A., 2017. Rhizosphere Microorganisms: Application of plant beneficial microbes in biological control of weeds. In: Microorganisms for Green Revolution (pp. 391-430). Springer, Singapore.

Sindhu, S.S., Gupta, S.K. and Dadarwal, K.R., 1999. Antagonistic effect of Pseudomonas spp. on pathogenic fungi and enhancement of growth of green gram (Vigna radiata). Biol. Fertil. Soils 29(1): 62-68.

Sindhu, S.S., Parmar, P., Phour, M. and Sehrawat, A., 2016. Potassiumsolubilizing microorganisms (KSMs) and its effect on plant growth improvement. In: Potassium solubilizing microorganisms for sustainable agriculture (pp. 171-185). Springer, New Delhi.

Sindhu, S.S., Sehrawat, A., Sharma, R. and Khandelwal, A. 2017a. Biological control of insect pests for sustainable agriculture. In: Advances in Soil Microbiology: Recent Trends and Future Prospects (pp. 189-218). Springer, Singapore.

Sindhu, S.S., Sehrawat, A., Sharma, R., Dahiya, A. and Khandelwal, A., 2017b. Below ground microbial crosstalk and rhizosphere biology. In: Plant-Microbe Interactions in Agro-Ecological Perspectives (pp. 695-752). Springer, Singapore.

Sindhu, S.S., Sehrawat, A., Sharma, R., Dahiya, A., 2016. Biopesticides: use of rhizosphere bacteria for biological control of plant pathogens. Def. Life Sci. J., 1: 135-148.

Sindhu, S.S., Sharma, R., Sindhu, S., and Sehrawat, A., 2018. Soil fertility improvement by symbiotic rhizobia for sustainable agriculture. In: Soil fertility management for sustainable development.Panpatte, D.G. and Jhala, Y.K. eds. Springer Nature, Singapore Pte Ltd. (In press).

Sindhu, S.S., Suneja, S., Goel, A.K., Parmar, N. and Dadarwal, K.R. 2002. Plant growth promoting effects of Pseudomonas sp. on 
coinoculation with Mesorhizobium sp. Cicer strain under sterile and "wilt sick" soil conditions. Appl. Soil Ecol., 19(1): 57-64.

Somers, E., Vanderleyden, J., and Srinivasan, M. 2004. Rhizosphere bacterial signalling: a love parade beneath our feet. Crit. Rev. Microbiol. 30(4): 205-240.

Souagui, Y., Grosdemange-Billiard, C., Tritsch, D., andKecha, M. 2015. Antifungal molecules produced by a new salt-tolerant and alkaliphilic Streptomyces sp. BS30 isolated from an arid soil. Proc. Natl Acad. Sci., India Section B: Biological Sciences 1-9.

Stokes, M.E. and McCourt, P., 2014. Towards personalized agriculture: what chemical genomics can bring to plant biotechnology. Front. Plant Sci., 5: 344.

Subramanian, S., Souleimanov, A. and Smith, D.L. 2016. Proteomic studies on the effects of lipo-chitooligosaccharide and thuricin 17 under unstressed and salt stressed conditions in Arabidopsis thaliana. Front. Plant Sci. 7:1314.

Teng, P.S. 2007. Business potential for agricultural biotechnology products. Report of the APO multi-country study mission.

Thomashow, L.S., and Weller, D.M. 1996. Current concepts in the use of introduced bacteria for biological disease control: mechanisms and antifungal metabolites. In: Plant Microbe Interactions (pp. 187235). Springer US.
Udvardi, M. and Poole, P.S. 2013. Transport and metabolism in legume-rhizobia symbioses. Annual Rev. Plant Biol. 64: 781-805.

Vessey, J.K. 2003. Plant growth promoting rhizobacteria as biofertilizers. Plant Soil 255(2): 571-586.

Wang, H., Yang, X., Guo, L., Zeng, H. and Qiu, D., 2015. PeBL1, a novel protein elicitor from Brevibacillus laterosporus strain A60, activates the defense responses and systemic resistance in Nicotiana benthamiana. Appl. Environ. Microbiol. pp.AEM-03586.

Wang, N., Liu, M., Guo, L., Yang, X. and Qiu, D. 2016. A novel protein elicitor (PeBA1) from Bacillus amyloliquefaciens NC6 induces systemic resistance in tobacco. Intern. J Biol. Sci. 12(6): 757.

Weller, D.M. 2007. Pseudomonas biocontrol agents of soil borne pathogens: looking back over 30 years. Phytopathology 97(2): 250-256.

Wong, P.T.W. and Baker, R. 1984. Suppression of wheat take-all and Ophiobolus patch by fluorescent pseudomonads from a Fusarium-suppressive soil. Soil Biol. Biochem. 16(4): 397-403.

Yasuda, M., Ishikawa, A., Jikumaru, Y., Seki, M., Umezawa, T., Asami, T., and Nakashita, H. 2008. Antagonistic interaction between systemic acquired resistance and the abscisic acid-mediated abiotic stress response in Arabidopsis. The Plant Cell 20(6): 1678-1692.

\section{How to cite this article:}

Ruchi Sharma, Anupma Dahiya and Satyavir Singh Sindhu. 2018. Harnessing Proficient Rhizobacteria to Minimize the Use of Agrochemicals. Int.J.Curr.Microbiol.App.Sci. 7(10): 31863197. doi: https://doi.org/10.20546/ijcmas.2018.710.369 